\title{
EDITORIAL
}

\section{Why Not Protein Science?}

In my editorial in the January issue of the journal, I raised the question "Why Protein Science?" and summarized the reasons that prompted The Protein Society to establish this new journal. Since then the project has been validated by the enthusiastic response of over 2,700 individual subscribers, a substantial increase in the membership of The Protein Society, and the acclamation of the interactive graphics features-Kinemage and The Protein Tourist - by authors, subscribers, and the scientific press. Our manuscript receipt continues to grow and we are taking steps to accelerate the publication of accepted manuscripts, particularly of seminal papers of timely importance. All of this is an encouraging and reassuring response, but we want to do better. It is our hope and intention to attract the best papers in the field of protein science, but in order to do so we need to induce potential authors to broaden their allegiance from journals in which they traditionally publish to include Protein Science.

There are several reasons why authors favor a particular journal for publication of their manuscripts. These reasons include, among others, the standing and prestige of a journal, its scientific slant, its readership, the names and reputations of the editor(s) and members of the Editorial Board, the speed of publication, the quality of print and illustrations, page charges and charges for reprints and color illustrations, and the like. In addition, the choice is guided by intangible preferences for journals in which related papers by professional colleagues, including competitors, are published.

An important criterion, particularly for choosing a new journal, is the citation of articles by abstracting services. In this connection, I am pleased to announce that, retroactive to Volume 1, Issue 1, papers published in Protein Science will be covered by Chemical Abstracts, CASI, Cambridge Scientific Abstracts, Current Contents/Life Sciences, SciSearch, Science Citation Index, and Research Alert. Others are expected to follow.

I am pleased to report that negotiations are under way for possible publication of Protein Science also on compact disk. This will facilitate storage and searching through past issues.

Protein Science was founded at the expressed desire of the members of The Protein Society, and as such it is their journal. If but one-fourth of the members would submit one important paper for publication annually, we would receive from them alone 50 manuscripts a month, which is more than enough to fill each issue. We do not expect exclusive loyalty to our journal, but we do want to remind the members of The Protein Society and others that, member or not, we want to serve the larger scientific community by publishing, as efficiently and promptly as possible, the best and most timely papers in this rapidly expanding branch of knowledge.

I have been asked on several occasions whether a certain topic is appropriate for publication in our journal. The science of proteins extends to the most advanced frontiers of chemistry, molecular biophysics, and molecular and cell biology, and we are anxious to reach out to them all. Representative topics of publication include protein folding and the role of chaperons, the molecular assembly of multidomain proteins, enzyme structure, mechanism and regulation, structural proteins, receptors and signalling, protein trafficking and sorting, nucleic acid-protein interactions, virus structure and assembly, membrane-associated proteins, proteins of the immune system, and any biological phenomena in which proteins of defined properties play a significant role. Manuscripts dealing with novel methodologies are also appropriate for publication in Protein Science, including protein sequencing by mass spectroscopy, time-resolved crystallography, multidimensional NMR spectroscopy, cDNA cloning, and mutagenesis, as well as computational analysis of protein structure. Contributions may take several forms and include, besides original papers, guest editorials, short reviews, Recollections, short "For the Record" announcements, and book reviews. We will also consider articles of other types on a case by case basis. If you are in doubt, send us your manuscript and we shall promptly advise you whether it falls within the editorial scope of the journal.

We are off to a great start, but we need your continued support if we are to achieve the goal of making Protein Science the leading journal in this area.

HANS NEURATH

Editor-in-Chief 